\title{
FABRIKASI SEL SURYA TERSENSITISASI DYE DENGAN ZNO NANOROD SEBAGAI FOTOANODA DAN MATERIAL SPIRO SEBAGAI HOLE TRANSPORT MATERIAL (HTM)
}

\author{
AFIFAH NURRIDA*, AYUNITA CHINTIA C, SHEILA SAKKYANANDA, ANNISA \\ APRILIA, TUTI SUSILAWATI, CUKUP MULYANA, LUSI SAFRIANI \\ Departemen Fisika Fakultas MIPA Universitas Padjadjaran, \\ Jl. Raya Bandung-Sumedang Km 21, Jatinangor 45363 \\ * email : nurridaafifah@gmail.com
}

\begin{abstract}
Abstrak. Dalam penelitian ini, kombinasi antara oksida logam $\mathrm{ZnO}$ nanorod dan $\mathrm{TiO}_{2}$ mesopori telah berhasil digunakan sebagai fotoanoda pada sel surya tersensitisasi warna. Selain itu, untuk meningkatkan difusi muatan di dalam sel, digunakan spiro-TPD (N,N'Bis-(3-methylphenyl)-N,N'-bis(phenyl)-9,9'-spirobifluorene) sebagai lapisan penghantar hole (HTM-hole transport material). Lapisan tipis ZnO dengan/tanpa aluminium ( $\mathrm{ZnO}: \mathrm{Al}$ seed layer (0 wt\%, 0,5 wt $\%$ dan $1 \mathrm{wt} \%)$ ) digunakan sebagai seed layer (lapisan penumbuh) dan dideposisikan di atas substrat FTO menggunakan teknik spin coating. Kemudian, $\mathrm{ZnO}$ nanorod ditumbuhkan di atas FTO/ZnO:Al seed layer menggunakan metode self-assembly dengan merendam FTO/ZnO:Al dalam larutan prekursor pada suhu $100^{\circ} \mathrm{C}$ selama 150 menit menggunakan oven elektrik. $\mathrm{ZnO}$ nanorod yang dihasilkan kemudian dikarakterisasi menggunakan SEM, dan hasil pengukurannya memperlihatkan bahwa $\mathrm{ZnO}$ nanorod yang ditumbuhkan di atas FTO/ZnO:Al (0,5 wt\%) memiliki diameter rata-rata terkecil sebesar $123 \mathrm{~nm}$ dan estimasi panjang sekitar $1,11 \mu \mathrm{m}$. Hasil spektrum XRD memperlihatkan bahwa seluruh sampel $\mathrm{ZnO}$ nanorod memiliki struktur heksagonal wurtzite dengan orientasi bidang hkl (002), dan memiliki ukuran bulir sekitar $15-25 \mathrm{~nm}$. Kombinasi $\mathrm{ZnO}$ nanorod dan $\mathrm{TiO}_{2}$ mesopori digunakan sebagai fotoanoda pada DSSC dengan struktur FTO/ZnO: $\mathrm{Al} / \mathrm{ZnO}$ nanorod/TiO $2 /$ ruthenizer 535bis TBA-dye/Spiro-TPD/ mosalit/Pt/FTO. Efisiensi tertinggi yang berhasil dicapai adalah $0,46 \%$ di bawah penyinaran $30 \mathrm{~mW} / \mathrm{cm}^{2}$ dengan menggunakan $\mathrm{ZnO}: \mathrm{Al}$ seed layer $(0,5 \mathrm{wt} \%)$.
\end{abstract}

Kata kunci : DSSC, spiro-TPD, $\mathrm{TiO}_{2}$ mesopori, $\mathrm{ZnO}$ nanorod

Abstract. Dye sensitized solar cell (DSSC) is one type of solar cell that interesting to researched. Basically, efficiency of DSSC is relatively low compared to other types of solar cells. One of the way to improve the efficiency of DSSC is modify photoanode structure and insert some material as hole transport material (HTM) to increase charge diffusion inside the cell. In this work, combination between metal oxides $\mathrm{ZnO}$ nanorod and $\mathrm{TiO}_{2}$ mesoporous was used to modify the photoanode structure. Moreover, in order to enhance charge diffusion inside the cell, Spiro-TPD (N,N'- Bis-(3-methylphenyl)N,N'-bis(phenyl)-9,9'-spirobifluorene) as hole transport material was employed. To initiate the nanorod growth, $\mathrm{ZnO}$ thin film with/without aluminum content ( $\mathrm{ZnO}: \mathrm{Al}$ seed layer- $0 \mathrm{wt} \%, 0.5 \mathrm{wt} \%$ and $1.0 \mathrm{wt} \%$ ) was used and deposited on FTO substrate using spin coating technique. After that, $\mathrm{ZnO}$ nanorod was grown on $\mathrm{FTO} / \mathrm{ZnO}$ :Al seed layer by using self-assembly methods; immersing $\mathrm{FTO} / \mathrm{ZnO}: \mathrm{Al}$ inside precursor solution at certain temperature $\left(100^{\circ} \mathrm{C}\right)$ for 150 minutes using laboratory oven. $\mathrm{ZnO}$ nanorod resulted then characterized by scanning electron microscope (SEM) and X-Ray Diffraction (XRD). SEM results show that $\mathrm{ZnO}$ nanorod growth on $\mathrm{FTO} / \mathrm{ZnO}: \mathrm{Al}(0.5 \mathrm{wt} \%)$ has the smallest average diameter $(123 \mathrm{~nm})$ and approximate length of $1.11 \mu \mathrm{m}$. XRD spectra reveal that all samples of $\mathrm{ZnO}$ nanorod have hexagonal wurtzite structure with (002) preferred orientation. Based on data processing of XRD spectra, $\mathrm{ZnO}$ nanorods have grain size ranges between $15-25 \mathrm{~nm}$. Combination between $\mathrm{ZnO}$ nanorod and $\mathrm{TiO}_{2}$ mesoporous was 
utilized as photoanode in DSSC with structure FTO/ZnO:Al/ZnOnanorod/TiO $/$ /ruthenizer 535-bis TBA-dye/Spiro-TPD/mosalyte/Pt/ FTO. The highest efficiency is $0.46 \%$ under $30 \mathrm{~mW} / \mathrm{cm}^{2}$ light irradiation, was obtained by using $\mathrm{ZnO}: \mathrm{Al}$ seed layer $(0.5 \mathrm{wt} \%)$ for nanorod growth.

Keywords : DSSC, spiro-TPD, TiO2 mesoporous, $\mathrm{ZnO}$ nanorod

\section{Pendahuluan}

Dye Sensitized Solar Cell (DSSC) atau sel surya berbasis zat warna tersensitisasi pertama kali ditemukan oleh Michael Gratzel pada tahun 1991 dan dipatenkan dengan nama Gratzel cell. DSSC konvensional telah banyak berkembang dari tahun ke tahun dan mencapai efisiensi 13\% sejak pertama kali ditemukan pada 1991 [1,2]. DSSC memiliki beberapa kelebihan dibandingkan dengan jenis sel surya lainnya yaitu fleksibilitas kimia dan kemudahan sintesis mendekati struktur molekul yang beragam, energik dan struktur yang halus, biaya rendah serta ramah lingkungan [3]. Karena keuntungannya, DSSC diprediksi akan menjadi divais energi untuk generasi yang akan dating [4]. Sel surya ini tersusun dari lima komponen utama, yaitu substrat konduktif, film tipis semikonduktor (fotoanoda), sensitiser atau zat warna, pasangan redoks (reduksi oksidasi) berupa elektrolit dan elektroda lawan (counter) [3].

Fotoanoda yang digunakan pada DSSC, merupakan jenis material metal oksida semikonduktor dan memiliki pengaruh yang cukup besar terhadap kestabilan dan efisiensi dari DSSC tersebut. Dari berbagai metal oksida yang berpotensi sebagai fotoanoda pada DSSC, zinc oxide ( $\mathrm{ZnO})$ memiliki beberapa kelebihan yaitu memiliki lebar pita yang sama dengan $\mathrm{TiO}_{2}$, mobilitas elektron lebih besar, pembuatannya lebih sederhana dan modifikasi permukaannya lebih mudah [5]. $\mathrm{ZnO}$ adalah salah satu oksida semikonduktor yang atraktif karena rentang resistivitasnya $\left(10^{-4}-10^{12} \Omega . \mathrm{cm}\right)$, lebar celah pitanya $(3,37 \mathrm{eV})$ dan besarnya energi ikat eksiton (60 meV) pada temperatur ruang [6].

Hole Transport Material (HTM) berfungsi untuk meningkatkan difusi muatan pada DSSC. Spiro-TAD dan SpiroTPD memiliki beberapa karakterisitik yang baik sehingga menjadikannya cocok sebagai hole transport material, yaitu temperatur transisi gelas atau glass transition temperature $\left(\mathrm{T}_{\mathrm{g}}\right)$ yang tinggi dengan struktur amorf, massa molar molekul yang rendah dan material spiro-TPD ini berbasiskan arylamines, yaitu memiliki daerah absorbansi pada rentang panjang gelombang ultraviolet (UV) sehingga proses penyerapan foton oleh sensitizer (dye) tidak akan terganggu [7].

\section{Metode Penelitian}

Bahan yang digunakan untuk preparasi $\mathrm{ZnO}$ seed layer adalah adalah zinc acetate dehydrate $\left(\left(\mathrm{Zn}\left(\mathrm{CH}_{3} \mathrm{CO}_{2}\right)_{2} .2 \mathrm{H}_{2} \mathrm{O}\right.\right.$, Aldrich, 98\%), 2-methoxyethanol, diethanolamine dan alumunium chloride $\left(\mathrm{AlCl}_{3}\right)$, serta zinc nitrate hexahydrate ( $\mathrm{Zn}(\mathrm{NO} 3) 2$. 6H2O, Aldrich, 98\%), hexamethylenetetramine (HMTA, Aldrich, 99\%) dan deionized (DI) water sebagai bahan/prekursor dalam pembuatan larutan penumbuh $\mathrm{ZnO}$ Nanorod. Sedangkan bahan yang digunakan untuk membuat larutan spiro adalah bubuk spiro-TPD dengan pelarut chlorobenzene. Bahan untuk fabrikasi DSSC adalah alkohol, etanol, aseton, pasta titanium dioksida $\left(\mathrm{TiO}_{2}\right)$ 
mesoporous T/SP (Solaronix), pasta titanium dioksida $\left(\mathrm{TiO}_{2}\right)$ macrochannel MC/SP (Solaronix), ruthenizer 535-bis TBA (Solaronix), chenodeoxycholic dan larutan garam ionik Mosalyte (Solaronix). Substrat konduktor yang digunakan adalah FTO (fluorine tin oxide) dan sebelum digunakan substrat tersebut dicuci terlebih dahulu dengan menggunakan teepol dan dikeringkan dengan menggunakan tisu lensa. Kemudian substrat dibersihkan dengan ultrasonic bath menggunakan etanol selama 10 menit. Kemudian substrat dibilas dengan aseton panas bersuhu $60^{\circ} \mathrm{C}$.

Zinc acetate dehydrate $\left(\left(\mathrm{Zn}\left(\mathrm{CH}_{3} \mathrm{CO}_{2}\right)_{2} .2 \mathrm{H}_{2} \mathrm{O}\right.\right.$, Aldrich, $\left.98 \%\right)$ sebanyak 0,548 gram dilarutkan dalam $5 \mathrm{ml}$ 2-methoxyethanol, setelah itu 12,5 ml diethanolamine ditambahkan secara perlahan-lahan. Kemudian menambahkan dopan alumunium chloride $\left(\mathrm{AlCl}_{3}\right) \quad 0,5 \mathrm{wt} \%$ dan $1 \mathrm{wt} \%$. Setelah larutan tercampur dengan baik dilakukan spin coating di atas substrat FTO dengan kecepatan 1500 rpm selama 30 detik. Proses pembuatan $\mathrm{ZnO}$ seed layer dilakukan dengan metode spin coating dan pre-heating pada suhu $250^{\circ} \mathrm{C}$ selama 10 menit untuk setiap lapisan, kemudian postheating pada suhu $500^{\circ} \mathrm{C}$ selama 30 menit. Zinc nitrate hexahydrate $\left(\mathrm{Zn}\left(\mathrm{NO}_{3}\right)_{2} \cdot 6 \mathrm{H}_{2} \mathrm{O}\right.$, Aldrich, 98\%) sebanyak 0,67 gram dilarutkan dalam $20 \mathrm{ml} \mathrm{DI-}$ water. hexamethylenetetramine (HMTA, Aldrich, 99\%) sebanyak 0,288 gram dilarutkan dalam $20 \mathrm{ml}$ DI-water. Setelah larutan homogen, kedua larutan dicampurkan dan diaduk selama 30 menit. $\mathrm{ZnO}$ seed layer yang telah dibuat di atas substrat FTO direndam pada larutan penumbuh nanorod dengan posisi facedown selama selama 150 menit dengan suhu $100^{\circ} \mathrm{C}$ di dalam oven elektrik. Selanjutnya film $\mathrm{ZnO}$ nanorod dibilas dengan DI-water dan ethanol lalu dilakukan annealing pada suhu $450^{\circ} \mathrm{C}$ selama 30 menit.

Lapisan $\mathrm{ZnO}$ nanorod pada substrat FTO (FTO/ZnO-Nr) kemudian dilapisi dengan pasta $\mathrm{TiO}_{2} \mathrm{~T} / \mathrm{SP}$ dengan teknik screen printing dan dilanjutkan pada proses preheating pada suhu $90^{\circ} \mathrm{C}$ selama 10 menit dan post-heating pada suhu $500^{\circ} \mathrm{C}$ selama 30 menit. Kemudian dilapisi dengan $\mathrm{TiO}_{2}$ MC/SP dengan proses pemanasan (heating) yang sama seperti $\mathrm{TiO}_{2} \mathrm{~T} / \mathrm{SP}$. Larutan dye (sensitizer) yang digunakan adalah ruthenizer seberat 20,8 mg dicampurkan dengan $200 \mathrm{mg}$ chenodeoxycholic dan $25 \mathrm{ml}$ etanol. Selanjutnya membuat larutan spiro-TPD 1,3\% dalam pelarut chlorobenzene sebagai material penghantar hole.

Elektroda kerja (FTO/ZnO-Nr/TiO $)$ direndam dalam larutan dye semalaman, kemudian dibilas dengan acetonitrile. Selanjutnya elektroda kerja tersebut dipanaskan pada suhu $70^{\circ} \mathrm{C}$ selama 10 menit. Kemudian dilapisi dengan larutan spiro menggunakan metode spin coating. Sebagai separator antara elektroda kerja dan elektroda lawan, Surilyn $(25 \mu \mathrm{m})$ digunakan untuk mencegah kontak antara keduanya, kemudan mosalit (elektroda cair) diinjeksikan melalui lubang pada sisi FTO/Pt.

\section{Hasil dan Pembahasan}

Hasil pengukuran difraksi sinar-X dari lapisan $\mathrm{ZnO}$ nanorod dengan variasi doping Al dapat dilihat pada Gambar 1. Gambar 1 memperlihatkan intensitas puncak difraksi yang tajam pada sudut $34^{\circ}$ menunjukkan dominasi puncak difraksi pada bidang hkl (002). Dominannya puncak difraksi (002) menyatakan bahwa ZnO dengan struktur batang (rod) telah terbentuk dengan arah pertumbuhan kristal ke 
sumbu-c. Selain itu, muncul puncak difraksi lainnya dengan intensitas yang rendah yaitu pada bidang kristal (101), (102), (103) dan (004). Keseluruhan puncak difraksi sinar-X bersesuaian dengan JCPDS (Joint Commitee on Powder Diffraction Standards) no. 36-1451 untuk kristal ZnO.

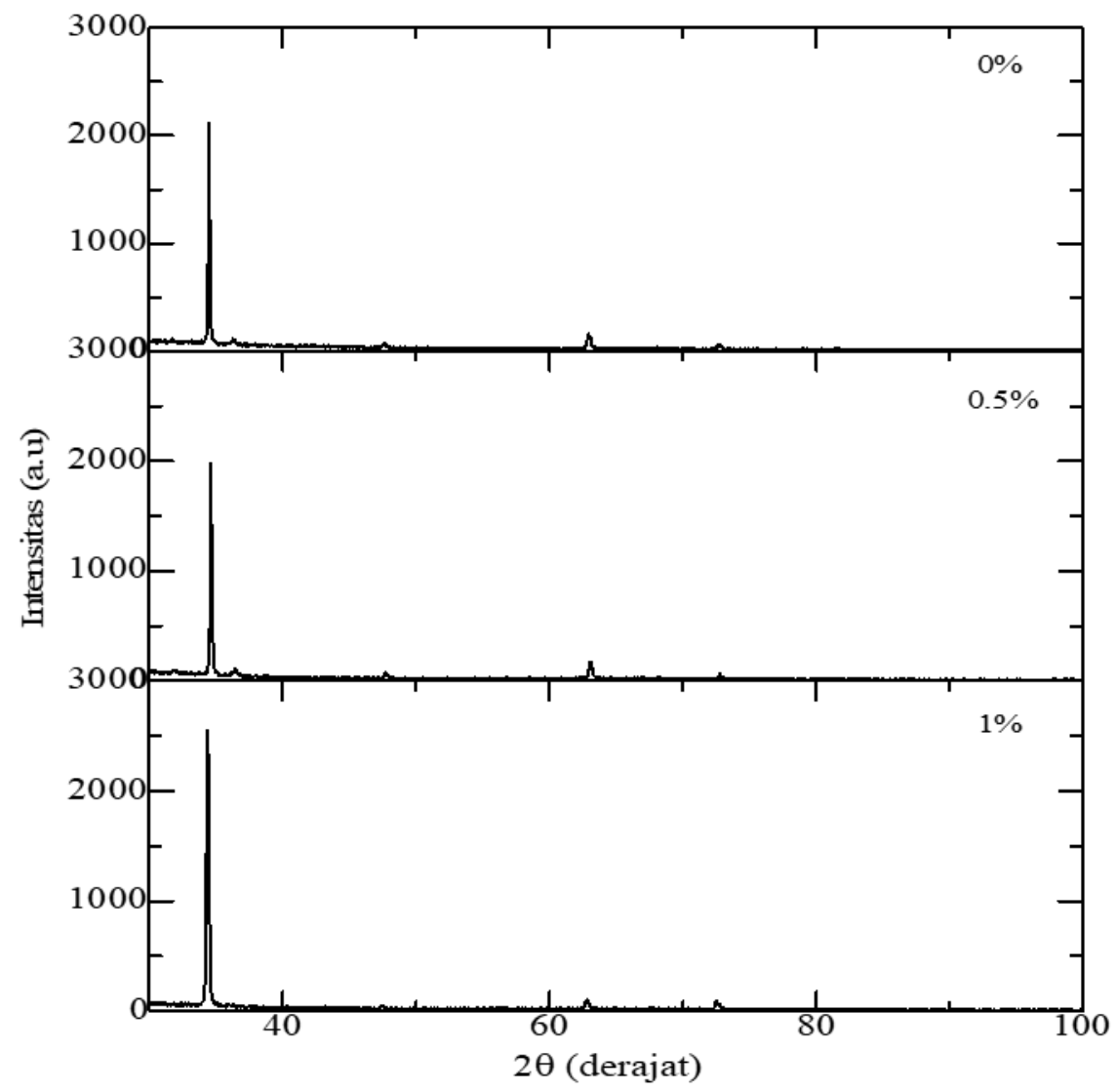

Gambar 1. Pola XRD ZnO nanorod

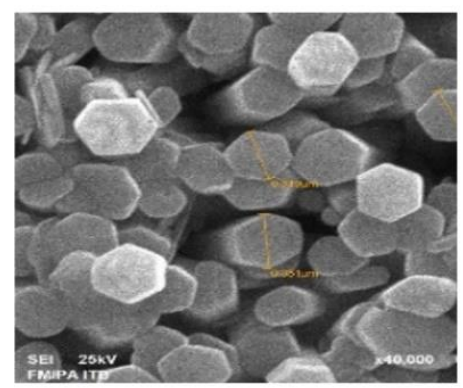

(a)

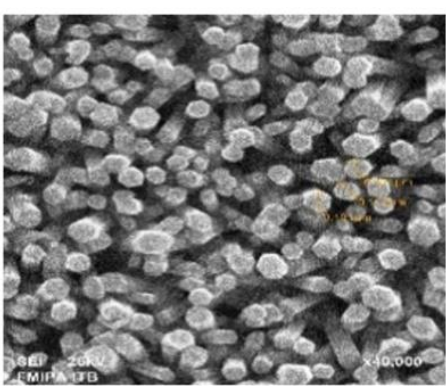

(b)

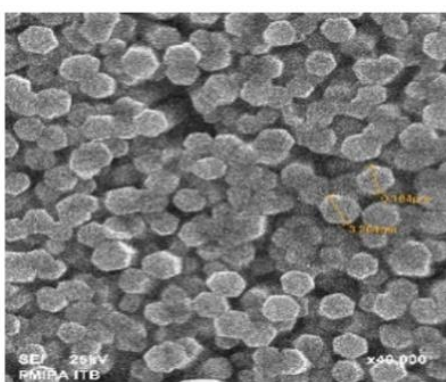

(c)

Gambar 2. Ukuran partikel pada temperatur proses (a) $800{ }^{\circ} \mathrm{C}$, dan (b) $1000{ }^{\circ} \mathrm{C}$

Hasil SEM permukaan lapisan $\mathrm{ZnO}$ nanorod dapat dilihat pada Gambar 2 dan memperlihatkan penjajaran $\mathrm{ZnO}$ nanorod yang terbentuk belum merata dengan ukuran diameter atau tidak homogen. Terlihat bahwa penambahan dopan alumunium ( $\mathrm{Al}$ ) dapat memperkecil diameter $\mathrm{ZnO}$ nanorod yang tumbuh dan diameter terkecil diperoleh ketika menggunakan seed layer dengan $\mathrm{ZnO}: \mathrm{Al}$ 0,5 wt\%. 
Tabel 1 memperlihatkan hasil pengukuran spektrum difraksi sinar-X dan perhitungan ukuran bulir/grain kristal $\mathrm{ZnO}$ yang membangun struktur rod menggunakan metode Debye-Scherrer. Terlihat bahwa semakin besar konsentrasi dopan alumunium dapat menyebabkan ukuran bulir kristal menurun. Penurunan ukuran diameter $\mathrm{ZnO}$ nanorod beserta bulir (grain size) berkaitan dengan kualitas permukaan dari seed layer. Penambahan dopan Al dengan konsentrasi tertentu dapat menyebabkan ukuran partikel $\mathrm{ZnO}$ menjadi lebih kecil sehingga menurunkan tingkat kekasaran permukaan [8]. Lapisan seed layer merupakan lapisan inisiator bagi pertumbuhan struktur $\mathrm{ZnO}$ nanorod, sehingga bentuk dan ukuran dari nanorod yang terbentuk secara tidak langsung berkaitan erat dengan kualitas seed layer [9]. Jika seed layer terdiri dari partikel (spherical) $\mathrm{ZnO}$ yang berukuran kecil maka struktur nanorod yang terbentukpun akan cenderung lebih kecil.

Tabel 1. Posisi puncak, estimasi ukuran bulir kristal dan parameter kisi c dari ZnO nanorod

\begin{tabular}{|c|c|c|c|c|}
\hline Orientasi Kristal & & 002 & & \\
\hline $\mathrm{Al}(\mathrm{wt} \%)$ & Posisi puncak (2Ө) & Ukuran Bulir (nm) & a $(\AA)$ & $c(\AA)$ \\
\hline 0 & 34,49 & 25,56 & 3,000 & 5,197 \\
\hline 0,5 & 34,63 & 21,12 & 2,988 & 5,176 \\
\hline 1 & 34,39 & 15,35 & 3,009 & 5,211 \\
\hline
\end{tabular}

Gambar 3 memperlihatkan kurva J-V (rapat arus-tegangan) DSSC dengan variasi fotoanoda dan tabulasi parameter kinerjanya diperlihatkan pada Tabel 2 . Kinerja atau efisiensi tertinggi diperoleh pada penggunaan seed layer $\mathrm{ZnO}$ didoping $\mathrm{Al}$ 0,5 $\mathrm{wt} \%$. Hal ini kemungkinan disebabkan oleh $\mathrm{ZnO}$ nanorod dengan seed layer $\mathrm{ZnO}: \mathrm{Al}(\mathrm{Al} \mathrm{0,5} \mathrm{wt} \%$ ) memiliki ukuran terkecil dengan kerapatan yang rendah, hal ini menyebabkan partikel $\mathrm{TiO}_{2}$ dan ruthenium dye lebih mudah mengisi pori - pori $\mathrm{ZnO}$ nanorod sehingga meningkatkan daerah persambungan (kontak). Hal ini terlihat dari nilai arus yang dihasilkan oleh sampel dengan penggunaan seed layer $\mathrm{ZnO}: \mathrm{Al}(0,5 \mathrm{wt} \%)$ paling besar diantara sampel lainnya.

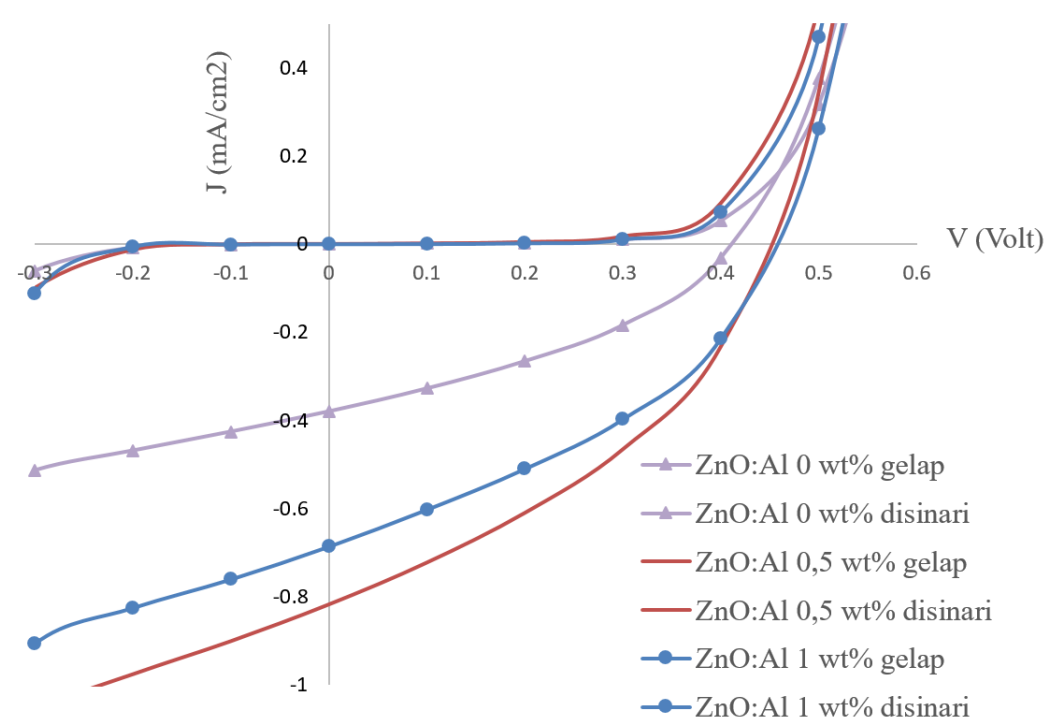

Gambar 3. Hasil SEM permukaan $\mathrm{ZnO}$ nanorod dengan variasi seed layer (a) ZnO undopped, (b) $\mathrm{ZnO}: \mathrm{Al}(0,5 \mathrm{wt} \%)$ dan (c) $\mathrm{ZnO}: \mathrm{Al}(1 \mathrm{wt} \%)$ 
Tabel 2. Karakteristik DSSC dengan variasi fotoanoda

\begin{tabular}{cccccc}
\hline Fotoanoda & $\begin{array}{c}\text { Luas Area } \\
\left(\mathbf{c m}^{\mathbf{2}}\right)\end{array}$ & $\begin{array}{c}\mathbf{J}_{\mathbf{s c}} \\
\left(\mathbf{m A / \mathbf { c m } ^ { 2 }}\right)\end{array}$ & $\begin{array}{c}\mathbf{V}_{\text {oc }} \\
(\mathbf{V o l t})\end{array}$ & $\begin{array}{c}\mathbf{F F} \\
(\boldsymbol{\%})\end{array}$ & $\begin{array}{c}\boldsymbol{\eta} \\
(\boldsymbol{\%})\end{array}$ \\
\hline $\begin{array}{c}\text { ZnO NR (ZnO seed layer } \\
\begin{array}{c}\text { undopped) } \\
\text { ZnO NR (ZnO:Al (0,5 wt\%) }\end{array}\end{array}$ & 0,12 & 0,38 & 0,43 & 30,25 & 0,18 \\
$\begin{array}{c}\text { seed layer) } \\
\text { ZnO NR (ZnO:Al (1 wt\%) seed } \\
\text { layer) }\end{array}$ & 0,12 & 0,82 & 0,48 & 35,56 & 0,46 \\
\hline
\end{tabular}

\section{Kesimpulan}

Semakin besar konsentrasi dopan alumunium dapat mengurangi ukuran bulir kristal dan mengurangi ukuran diameter dari $\mathrm{ZnO}$ nanorod. Namun masih diperlukan optimasi nilai konsentrasi dopan alumunium agar pertumbuhan nanorod bisa lebih merata, ukuran diameter $\mathrm{ZnO}$ nanorod lebih homogen dan kerapatannya lebih rendah. Saat $\mathrm{ZnO}$ nanorod diaplikasikan pada DSSC diperoleh efisiensi tertinggi 0,46\% pada ZnO:Al (0,5 wt\%) seed layer disebabkan diameter nanorod yang dihasilkan terkecil dan kerapatannya rendah. Hasil ini menunjukkan $\mathrm{ZnO}$ nanorod yang dikombinasikan dengan $\mathrm{TiO}_{2}$ mesopori dapat diaplikasikan sebagai fotoanoda pada DSSC.

\section{Ucapan terima kasih}

Penulis mengucapkan terima kasih kepada Direktorat Penelitian, Pengabdian Kepada Masyarakat dan Inovasi (DRPMI) Universitas Padjadajaran yang telah memfasilitasi penyaluran dana penelitian PUPT (Program Unggulan Perguruan Tinggi), nomor kontrak No. 431/UN6.3.1/PL/2016.

\section{Daftar Pustaka}

1. S. Mathew et al., Dye-sensitized solar cells with $13 \%$ efficiency achieved through the molecular engineering of porphyrin sensitizers. Nat. Chem. Vol 6 (2014) p. 242-247.

2. O'regan, MGratzel, A LowCost, High Efficiency Solar Cell Based On DyeSensitized Colloidal Tio2 Films. Vol. 353 (1991) p. 1-9.

3. I. N. Obotowo, I. B. Obot, U. J. Ekpe, Organic sensitizers for dye-sensitized solar cell (DSSC): Properties from computation, progress and future perspectives. J. Mol. Struct. Vol. 1122 (2016) p. 80-87.

4. B. Basheer, D. Mathew, B. K. George, C. P. Reghunadhan Nair, An overview on the spectrum of sensitizers: The heart of Dye Sensitized Solar Cells. Sol. Energy Vol. 108 (2014) p. 479-507.

5. C. H. Chao, C. H. Chan, J. J. Huang, L. S. Chang, H. C. Shih, Manipulated the band gap of $1 \mathrm{D} \mathrm{ZnO}$ nano-rods array with controlled solution concentration and its application for DSSCs. Curr. Appl. Phys. Vol. 11 (2011) p. S136-S139.

6. K. Kim, K. Utashiro, Y. Abe, M. Kawamura, Structural Properties of Zinc Oxide Nanorods Grown on Al-Doped Zinc Oxide Seed Layer and Their Applications in Dye-Sensitized Solar Cells. Materials (Basel). Vol. 7 (2014) p. 2522-2533. 
7. E. Nurazizah, Karakterisasi film tipis spiro-TAD dan spiro-TPD sebagai lapisan pembawa muatan untuk aplikasi divais sel surya organik. Skripsi Fis. Mater. Univ. Padjadjaran (2016).

8. A. Aprilia, P. Wulandari, V. Suendo, Herman, R. Hidayat, A. Fujii, M. Ozaki, Influences of dopant concentration in sol-gel derived AZO layer on the performance of P3HT:PCBM based inverted solar cell, Solar Energy Material \& Solar Cells Vol. 111 (2013) p. 181-188.

9. L. Hyukjae, S. Jun-Ho, C. Jisu, K. Jung Bin, K. Tae-Huei, P. Kyung-Bong, Effect of Seed Layer Prepared Under Various Heating Conditions on Growth of $\mathrm{ZnO}$ Nanorod Arrays for Dye Sensitized Solar Cells, Electronics Materials Letters, Vol.9 Issue 3 (2013) p 367-362 